\title{
The Royal House of Isabel I of Castile (1492-1504): use of silk, wool and linen according to the accounts of Gonzalo de Baeza
}

\author{
Nadia Fernández de Pinedo ${ }^{1, *}$ (D) \\ María Paz Moral² \\ ${ }^{1}$ Departamento de Análisis Económico: Teoría Económica e Historia Económica, Universidad Autónoma de \\ Madrid, España \\ ${ }^{2}$ Departamento de Economía Aplicada III (Econometría y Estadística), Universidad del País Vasco, UPV/EHU, \\ España \\ *nadia.pinedo@uam.es
}

\section{Abstract}

Thanks to the conservation of the expense accounting of the Royal House of Isabel I of Castile (1492-1504), it is possible to analyze the consumption of silk, wool and linen fabrics (excluding fabric with metal threads) by class status from the time of the discovery of America to the death of the queen. The most frequently used fabrics by quantity was linen, followed by wool and silk. By cost, however, silk reached $60 \%$ of expenses, followed by wool (31\%) and linen ( $8 \%)$. As the accounts move down the social ladder, silk disappears altogether, while wool and linen remain. Attending to the colour, black was the most commonly used dye for silk fabrics and red was the most common dye for wool.

\section{A Casa Real da Rainha Isabel I de Castela (1492-1504): consumo de seda,}

lã e linho de acordo com as contas de despesa de Gonzalo de Baeza

\section{Resumo}

Graças à preservação das contas de despesa da Casa Real da Rainha Isabel I de Castela (1492-1504), é possível analisar o consumo de tecidos em seda, lã e linho (com excepção de tecidos com fios metálicos) por estatuto social desde o ano do descobrimento da América até à morte da rainha. $\mathrm{O}$ tecido mais usado em quantidade era o linho, seguido da lã e da seda. Em termos de valor monetário, contudo, a seda alcançava $60 \%$ das despesas, seguida da lã (31 \%) e do linho (8 \%). Assim que as contas descem na escala social, a seda desaparece completamente, enquanto que a lã e o linho se mantêm. Em relação à cor, o negro era o corante mais usado em tecidos de seda, e o vermelho, o mais comum em lãs.

\section{Keywords}

Consumption

Textiles

Colours

Isabel I

Social status

\section{Palavras-chave}

\section{Consumo}

Têxteis

Corantes

Isabel I

Estatuto social 


\section{Introduction}

A large number of historians have studied the reign of the Catholic Kings, especially the power relations in the court, and the fiscal, political and cultural aspects of their reign [1-11]. The abundance of existing documentation by official royal chroniclers has been vital for expanding this knowledge [12]. The purpose of this article, however, is to focus not on the reign but on the court's purchases and consumption. We examine the shopping basket and the weight that fabric spending had and analyse fabric consumption at the turn of the fifteenth century. As Braudel pointed out, beyond the economic implications of the manufacture of fabrics, "l'histoire des costumes est moins anecdotique qu'il n'apparaît. Elle pose tous les problèmes, ceux des matières premières, des procédés de fabrication, des couves de revient, des fixités culturelles, des modes, des hiérarchies sociales" [13, p. 271].

It is important to remember two factors. On the one hand, the Court of the Catholic Kings was itinerant, which had implications from the point of view of consumption [14]. It was necessary to wrap, pack and move the necessary and essential household items as well as those of high value, while other goods were acquired after the court was installed again in another city. This itinerancy implied that only the staff of the court which was indispensable, as well as a part of the "Council with a secret seal or of priority" [15] accompanied the Monarchs. Nevertheless, during the reign of the Catholic Kings, there was actually an increase in the staffing of the Royal House [15] and enactment of court regulations to control and define social behaviour and dress. It is important to note that the House of the Queen of Castile functioned as a platform for social promotion in which Castilian nobility, in order to promote themselves, sought employment for their children as maids, servants or pages [16]. In fact, the House of the Queen was in charge of the infantes (the monarch's sons and daughters) as well as the pages and maids that were raised in the court. Hence, the population of the House of the Queen oscillated between 400 and more than 1,000 people [15].

Sumptuary legislation tried to regulate their image. The Catholic Kings promulgated the Pragmática Sanción of September 2, 1494 on clothing [17-18], which prohibited both the nobility and the lower classes from wearing costly clothes made with silks or furs, which was reserved for the royalty. This continued the tradition of ordinances and sumptuary legislation from the reign of Alfonso X El Sabio (1252-1284), who limited ostentation and regulated the use of certain fabrics, materials (e.g., embroidery of gold or silk threads) and colours by certain social groups [19-21]. The origin of sumptuary laws in all medieval kingdoms can be traced back to Italian cities at the end of the 12th century [22-24]. The regulations controlled both the type of fabrics and colours allowed. For example, Sas van Damme noted that the Castilian Cortes regulated what colours could be worn by Moors and Jews [25, p. 245].
Skilled dyers and commercial networks (exporters and importers of the needed natural colorants) were key elements in the textile industry [26]. The relevance of textiles and empire networks is shown by Ferreira [27] and Cardon, among others, [28-30] who analyse dyes, technical advances and pricing. Dyes were important as they determined to a large extent the price of the dyed fabric and therefore the status of the owner [28]. The nuances and tones of black, blue, red, violet and pink depended largely on the chemical reaction to fix the colour; this was achieved by using the correct compound of dyes, mordants (alum) and additional ingredients, such as rancid olive oil. Skilled dyers and quality dyestuff were essential, which is why dyeing "was often the greatest cost factor in production" and "dyers were the elite of cloth manufacture" [31]. As Finlay noted, "dyed garments were the most visible, widespread, and extensively used signs of social status and conspicuous consumption" [32].

\section{Information from the source: fabrics}

In general, the archival sources used to analyse consumption in the medieval and modern eras are trousseaux, post-mortem inventories, material objects and iconography. A wide bibliography exists on the uses and customs of Isabel I, and in particular on her belongings [33-34], that to some extent is based on her will [35] and the accounts of her treasurer. One often used source is Cuentas de Gonzalo de Baeza, Tesorero de Isabel la Católica (Accounts of Gonzalo de Baeza, Treasurer of Isabel la Católica; hereafter Accounts of the treasurer) [36], which is a document that records in great detail the expenditures incurred by the Royal House of Isabel I. It was edited and published in 1955-1956 in two volumes: the first for the years 1477-1491 and the second for 1492-1504, or from the discovery of America until the death of Isabel. Previous studies have analysed his source for specific purposes, such as the information on a year or a specific person (e.g. singers, chaplains or certain members of the nobility), object or fabric. For this article, a systematic analysis of the information in the second volume was carried out and a database created to analyse the shopping basket of the Queen's household and the relative weighting of fabric expenses. It is important to note that the Accounts of the treasurer has its limitations. For example, it did not include the expenses of the king. Even so, it contains in detail the expenses of Isabel, her children, servants, and donations of fabric to the poor. Another limitation is that, with a few exceptions, the places of origin of fabric are missing. Nevertheless, the Accounts of the treasurer is full of information related to textiles, fibres, and colours. The results relating to the years 1483-1491 have been published in Fernández de Pinedo \& Moral [37]. Following these authors, we focus only on the fabrics and dyes made from plants and animals. We excluded those textiles whose fibre was made from gold or silver as well as the trousseau of the princesses because they were very costly or specific 
expenses that could have caused bias in the sample and the consequent shopping basket.

All the items related to fabric expenses in volume 2 were added to our database, and we included 12 variables organized into two categories. The first category is the purchase itself, and includes the year and place of purchase, description of the product - including type of fabric and colour -, quantity, unit of measure, price, currency used and the cost. To standardise the information, we then took all purchases and converted them using a single measurement of length - the Castilian vara (equals approximately 0.8359 meters) - and the price paid and value of the fabric into a monetary unit the maravedi ( $m r s)$. The second category is the ultimate use of the product; that is, the purpose it would be used for (clothing, white clothes, church, travel, etc.) and the person to whom it was allotted.

With some data excluded (e.g. materials made of gold or silver threads), we obtained 6,287 entries, of which we used 4,668. These correspond to information in Accounts of the treasurer that included at least three basic data points: price, amount and the recipient. We ruled out 1,619 entries because the minimum information needed was not available.

See Table 1 for a comparison of the distribution of textile use between 1483-1491 and 1492-1504. On average, the number of varas decreased approximately $16.5 \%$ per year. However, the change in the type of fabric was more significant. Although linen remained the most used material (at nearly $50 \%$ ), wool (at $30 \%$ ) clearly displaced silk from second place. One reason for this change was the reduction in the size of the royal family, mainly due to the marriages of the infantas and the departure of the sons of the Duke of Braganza (one of whom is discussed below). However, the personnel assigned to the security of the royal family grew such that "the increase in expenditure coincides with the development of the ceremonialization of the acts of the monarchy" [38, p. 20].

With fewer people of high income and status in the court, the amount of silk and linen used in clothing, bedding and table service (such as tablecloths), decreased. Meanwhile, both the relative and absolute weight of woollen fabrics increased. This may be because woollens were part of Isabel's donations of fabrics and clothing to the court's servants. Most likely, these donations followed the sumptuary laws and social hierarchy as in northern Italy in the 14th century, as noted in Buss [22, p. 37].

In analysing the value of the textiles from 1483 to 1491 , we found the amount slightly modified but the ranking did not change: silk represented almost two-thirds, wool nearly one-third and linens the rest. It is worth mentioning the increase in the use of wool over linen and silk. Linen was used undyed and had a great variety of uses, from wrapping household items, to tablecloths, and to shirts. Silk, although it could also be used for bed sheets and undergarments, was mostly used for outer clothing, as was wool. This could explain why the amount spent on wool increased mostly in relation to silk but not linen. It should also be noted that other fibres, such as cotton or hemp, had a negligible weight from 1483 to 1504.

Data from 1492 to 1504 mostly does not differ from the previous period in terms of usage: in terms of varas, linen is the highest; in terms of value, it is silk. Tables 2-4 allow a closer look at the fabrics. We found a great variety of names associated with the fabrics. The names do not imply the technical description but rather the type of fibre, colour, and even decoration, similar to Cabrera [39, p. 10]. We provide the original names of the fabrics; we translated the names using specialized dictionaries [2324, 40-46].

\section{Table 1}

Consumption of fabrics by the Queen's house, annual average 1483-1491 and 1492-1504

\begin{tabular}{|c|c|c|c|c|c|c|c|c|}
\hline \multirow{3}{*}{ Fiber } & \multicolumn{4}{|c|}{ Quantity } & \multicolumn{4}{|c|}{ Value } \\
\hline & \multicolumn{2}{|c|}{$1483-1491$} & \multicolumn{2}{|c|}{$1492-1504$} & \multicolumn{2}{|c|}{$1483-1491$} & \multicolumn{2}{|c|}{$1492-1504$} \\
\hline & Varas & $\%$ & Varas & $\%$ & Maravedis & $\%$ & Maravedis & $\%$ \\
\hline Linen & $2,474.4$ & 64.64 & $1,583.5$ & 49.55 & $184,025.8$ & 11.12 & $93,886.7$ & 7.94 \\
\hline Silk & 847.5 & 22.14 & 618.0 & 19.34 & $1,244,737.8$ & 75.25 & $713,965.8$ & 60.37 \\
\hline Wool & 482.6 & 12.61 & 972.8 & 30.44 & $224,360.2$ & 13.56 & $372,353.3$ & 31.48 \\
\hline Cotton & 12.6 & 0.33 & 11.7 & 0.37 & 461.3 & 0.03 & 725.9 & 0.06 \\
\hline Hemp & 5.3 & 0.14 & 3.8 & 0.12 & 448.4 & 0.03 & 87.4 & 0.01 \\
\hline Other / unknown & 5.5 & 0.14 & 6.2 & 0.20 & 139.8 & 0.01 & $1,641.4$ & 0.14 \\
\hline Total & $3,827.9$ & 100.00 & $3,196.0$ & 100.00 & $1,654,173.3$ & 100.00 & $1,182,660.5$ & 100.00 \\
\hline
\end{tabular}

Notes:

Data for 1483-1491 are taken from Fernández de Pinedo \& Moral [37].

1 vara $\approx 0.8359$ meters. 
Table 2

Silk: quantity (varas) and value (maravedis), by type of fabric, annual average 1492-1504

\begin{tabular}{|c|c|c|c|c|c|}
\hline \multirow{2}{*}{ Tejido / Fabric } & \multicolumn{2}{|c|}{ Quantity } & \multicolumn{2}{|c|}{ Value } & \multirow{2}{*}{$\begin{array}{c}\text { Average } \\
\text { price per vara }\end{array}$} \\
\hline & Varas & $\%$ & Maravedis & $\%$ & \\
\hline Brocado / Brocade* & 27.87 & 4.51 & $147,591.25$ & 20.67 & $5,295.46$ \\
\hline Altibajo & 9.84 & 1.59 & $23,459.52$ & 3.29 & $2,385.00$ \\
\hline Villutado & 2.61 & 0.42 & $5,463.23$ & 0.77 & $2,096.71$ \\
\hline Carmesí de pelo / Crimson velvet (non sheared) & 3.09 & 0.50 & $6,423.08$ & 0.90 & $2,078.84$ \\
\hline Aceituní & 15.16 & 2.45 & $23,886.42$ & 3.35 & $1,575.59$ \\
\hline Otros / Others & 9.69 & 1.57 & $12,206.15$ & 1.71 & $1,260.20$ \\
\hline Terciopelo / Velvet & 304.34 & 49.25 & $330,644.20$ & 46.31 & $1,086.45$ \\
\hline Carmesí raso / Dark red satin & 0.35 & 0.06 & 368.46 & 0.05 & $1,064.44$ \\
\hline Çebti** & 59.84 & 9.68 & $45,605.40$ & 6.39 & 762.17 \\
\hline Raso / Satin & 100.63 & 16.29 & $70,685.93$ & 9.90 & 702.40 \\
\hline Damasco / Damask & 74.34 & 12.03 & $44,463.37$ & 6.23 & 598.08 \\
\hline Tafetán / Taffeta & 10.21 & 1.65 & $3,168.81$ & 0.44 & 310.31 \\
\hline Total & 617.96 & 100.00 & $713,965.82$ & 100.00 & $1,155.37$ \\
\hline
\end{tabular}

* Brocado: According to Bernis, brocade was a fabric made of silk, gold and silver decorated with motifs on the background in light relief (trees, flowers, artichokes, pineapples, leaves) [18, p. 21].

** Çebty or 'zetani'. Cebty is a silk fabric, originally from Ceuta (hence the name of cebty) imitated by the Italian silk manufactures, from where it was later imported to the Peninsula. According to Luca Mola, it is a common definition for a silk cloth of the 15th century (especially in Florence, Lucca but also Venice), which tends to disappear afterwards. Originally it indicated a dense and heavy satin. By the 16th century, instead, the word "raso" became usual for satin, and "zetani" is not mentioned anymore.

In the case of silk, we collected no less than 11 types of textiles, with an average price of 1,155 mrs/vara (Table 2). Above that average price, is brocado (brocade), which was not affordable by anyone but royalty, and altibajo (embroidered velvet), carmesí de pelo, aceituní and villutado.

The number of varas of all above-average priced fabrics combined was less than $11 \%$ of the total. Velvet, with a price a little higher than 1,000 mrs/vara, accounts for $50 \%$ of all silk fabrics. Velvet is followed by four fabrics (çebty, damask, satin and taffeta), which combined represent almost $40 \%$ of the total of material all under $800 \mathrm{mrs} / \mathrm{vara}$. Considering price, velvet leads the ranking (46\% of total value), followed by brocade (with more than $20 \%$ ). The least expensive silk fabrics represent only $23 \%$ of the total value.

Wool fabrics, by comparison, had an average price of $383 \mathrm{mrs} /$ vara (Table 3). Only two fabrics, grana or cochinilla and limiste surpassed the 1,000 mrs/vara, although, on the whole, these last two had little weight.

Most of the wool fabrics (60\% of total varas) were below the average price, including pardillo (woollen cloth), buriel (coarse woollen), and frisa (frieze or woollen serge). These cheap woollen fabrics were mainly used by lower-income populations and mendicant friars. As Scott noted, "the clothing of the lower classes drew on a much more limited range of fabrics, dictated by practicality and cost. Even colors, especially crimson, could be forbidden to them and restricted to the upper classes. At the lower social levels, rough, undyed woollens were worn over coarse linens" [47, p. 12].

"Other woollen cloths" includes those with a low percentage share and which usually bore the name of the place of origin. In general, these were above the average price, as in the case of cloths made in Valencia and Rouen. The most expensive woollen cloth was from Florence, costing 1,150 mrs/vara on average. Their high relative weight in this category - $28 \%$ in varas and $23 \%$ in value - is because this category includes all entries using the generic term paño (cloth).

Linen was the fabric most often purchased, was certainly the cheapest, and the least often used in outer clothing; nevertheless, as stated by Bernis, Spanish Christians wore linen garments through the influence of Andalusian Muslims [18, v1, p. 26]. The variety in quality and prices was based on the material's thickness. A lightweight fabric was used for shirts, sheets and mattresses. Linen garments were often donated to the poor after the original owner died. This is one reason why its presence post-mortem tends to be underestimated and its usage is generally unnoticed. In addition, linen, especially the cheap or very cheap varieties, was a fabric for self-supply (e.g., someone 
Table 3

Wool: quantity (varas) and value (maravedis), by type of fabric, annual average 1492-1504

\begin{tabular}{|c|c|c|c|c|c|}
\hline \multirow{2}{*}{ Tejido / Fabric } & \multicolumn{2}{|c|}{ Quantity } & \multicolumn{2}{|c|}{ Value } & \multirow{2}{*}{$\begin{array}{c}\text { Average } \\
\text { price per vara }\end{array}$} \\
\hline & Varas & $\%$ & Maravedis & $\%$ & \\
\hline Limiste & 0.62 & 0.06 & 738.46 & 0.20 & $1,200.00$ \\
\hline Grana / Cochineal & 102.38 & 10.52 & $109,465.28$ & 29.40 & $1,069.20$ \\
\hline Finamarcha & 3.31 & 0.34 & $2,613.85$ & 0.70 & 790.23 \\
\hline Contray / Cloth of Courtray & 158.46 & 16.29 & $88,891.22$ & 23.87 & 560.95 \\
\hline Londres / London & 119.00 & 12.23 & $46,787.49$ & 12.57 & 393.17 \\
\hline Otros / Other woollen cloths & 236.94 & 24.36 & $78,533.87$ & 21.09 & 331.45 \\
\hline Palmilla & 10.04 & 1.03 & $2,446.31$ & 0.66 & 243.69 \\
\hline Estameña / Tammy* & 18.24 & 1.88 & $4,109.38$ & 1.10 & 225.27 \\
\hline Segovia & 32.68 & 3.36 & $6,243.23$ & 1.68 & 191.05 \\
\hline Brunete / Coarse woollen & 1.88 & 0.19 & 353.15 & 0.09 & 187.39 \\
\hline Cordellate / Kersey & 5.40 & 0.55 & 813.46 & 0.22 & 150.71 \\
\hline Paño pardillo / Woollen cloth pardillo & 121.92 & 12.53 & $17,106.05$ & 4.59 & 140.31 \\
\hline Buriel / Coarse woollen & 87.27 & 8.97 & $10,062.23$ & 2.70 & 115.30 \\
\hline Blanqueta / Coarse woollen & 0.19 & 0.02 & 19.23 & 0.01 & 100.00 \\
\hline Luto / Mourning clothes & 22.08 & 2.27 & $2,111.31$ & 0.57 & 95.63 \\
\hline Frisa / Frieze & 12.52 & 1.29 & 660.96 & 0.18 & 52.80 \\
\hline Sarga / Woollen Serge & 21.46 & 2.21 & $1,084.00$ & 0.29 & 50.51 \\
\hline Sayal / Coarse woollen & 18.46 & 1.90 & 313.85 & 0.08 & 17.00 \\
\hline Total & 972.85 & 100.00 & $372,353.33$ & 100.00 & 382.75 \\
\hline
\end{tabular}

*According to Nemnich and Beck, estameña is translated as tammy [45-46].

Table 4

Linen: quantity (varas) and value (maravedis), by type of fabric, annual average 1492-1504

\begin{tabular}{|c|c|c|c|c|c|}
\hline \multirow{2}{*}{ Tejido / Fabric } & \multicolumn{2}{|c|}{ Quantity } & \multicolumn{2}{|c|}{ Value } & \multirow{2}{*}{$\begin{array}{c}\text { Average } \\
\text { price per vara }\end{array}$} \\
\hline & Varas & $\%$ & Maravedis & $\%$ & \\
\hline Cambray / Cambric & 1.04 & 0.0 & 302.31 & 0.32 & 291.11 \\
\hline Manteles / Linen Tablecloths & 54.71 & 3.46 & $11,627.06$ & 12.38 & 212.51 \\
\hline Holanda / Holland & 300.30 & 18.96 & $35,511.14$ & 37.82 & 118.25 \\
\hline Naval & 326.68 & 20.63 & $13,884.36$ & 14.79 & 42.50 \\
\hline Lienzo / Plain linen & 216.73 & 13.69 & $9,056.93$ & 9.65 & 41.79 \\
\hline Otros / Others & 150.15 & 9.48 & $6,177.51$ & 6.58 & 41.14 \\
\hline Bretaña / Bretagne & 474.07 & 29.94 & $15,477.49$ & 16.49 & 32.65 \\
\hline Vitre / Ravensduck & 59.81 & 3.78 & $1,849.93$ & 1.97 & 30.93 \\
\hline Total & $1,583.49$ & 100.00 & $93,886.73$ & 100.00 & 59.29 \\
\hline
\end{tabular}


who produces and then personally uses the fabric) or distributed amongst specific networks.

On average, 1,583 varas of different linens were purchased annually, mainly from Bretagne, and mostly naval and Holland linens (70 \%). Linen fabric was not expensive, with the average price being $59 \mathrm{mrs} / \mathrm{vara}$. Only the Holland (118 mrs/vara), tablecloths (213 mrs/vara) and cambray (291 mrs/vara) were above the average price (Table 4).

We found more than 18,000 varas of linen, with their purpose specified, for the period. This represents $88 \%$ of the total linen fabrics (Table 5). Most linens, measured in both varas and value, were furnishing and household textiles, such as tablecloths, followed by shirts and bedding (pillows, sheets, kirtles). The heterogeneous rest includes garments such as skirts, coifs, etc. As the court was itinerant, essentials such as glassware, place settings and silver objects were wrapped in linen for safe transport. Some objects had to use specific types of linen; for example, linen from Bretagne was used to wrap knifes and chalices; naval to wrap glasses; vitre (rough linen) for silver; linen from Flanders for bed chamber clothing; white linen for angarillas; white waxed linen for coffers, wooden cabinets and some items from the House of the Queen.

Thanks to Accounts of the treasurer, we were able to study not only the most visible fabrics (used for outer clothing) but also less visible fabrics (used for undergarments, tablecloths, and wrapping household items). It emphasizes the weight of linen, at least quantitatively. Each researcher has used the information in the main source for different purposes and to highlight different aspects of life. In our case, although Accounts of the treasurer accounts for the importance of linen, it must be remembered that in analysing post-mortem inventories, linen was usually undervalued and even absent. Therefore, we had to be cautious about not generalizing.

\section{Garments and linings}

The Middle Ages was a turning point in many ways. Bernis indicates that changes in clothing can be noticed in the 14th century, for example from simple dresses to garments that enhanced the silhouette of both men's and women's body [18, 48]. This change clearly differentiated the dress of men and women, and brought a greater richness and variety of clothing, especially for the most privileged classes. Nobles began to hire personal foreign or national tailors. The professionalization of clothing trades, such as tailors, seamstresses and furriers, was consolidated [49, p. 75]. However, it will not be until last third of the 16th century when the main tailoring treaties appeared in order to standardize clothing models, describe new measurement techniques, offer advice on making garments and economising on fabrics. In any case, the Catholic Kings regulated textile production to encourage the manufacture of higher-quality cloths and face foreign competition, protecting the guilds.

During the 15th century, there were changes in braies (undergarments) for men and shirts for men and smocks for women, hose for both; semi-inner garments (jubón, cos, faldilla, gonete, basquiña, hose); outer garments for clothing (cotte, brial or gonela for women and jaquetas, ropas or sayos for men); suits (mongiles, hábitos, sobresaya, marlotas), and overcoats (tabardo, capuz, gabán, mantle,cloak, albornoz) [18, pp. 35-38; 50]. Bernis points out that Spanish fashion had several influences, starting with the French (especially for men's clothing until approximately 1470) and the Italian (at the end of 15 th century), and also from the Moors (especially in garments and dresses). These influences combined with national tastes to give rise to original creations. The main changes were to the masculine suit by the shortening of top garments, and the cotte and the tunic being replaced by the tighter fitting doublet, or jubón; by shortening the length of women's skirts; and by the diffusion of the jubón and the jaqueta adjusted to the torso. Women, as happened in Italy, began to wear open sleeves in order to show the shirt. In fact, scotamocks with embroidered sleeves were already in use in 13th century Spain. By exposing the shirt to the elbow, this favoured sleeves or manguitos that covered the forearms [51, pp. 110-111]. They continued wearing all kinds of overcoats, especially the capuces and tabardos, and the cloaks with sleeves or that were open on the sides. The so-called verdugos, which helped to create

Table 5

Linen: declared purpose of 18,091 varas (1492-1504)

\begin{tabular}{|c|c|c|c|c|}
\hline \multirow{2}{*}{ Purpose } & \multicolumn{2}{|c|}{ Quantity } & \multicolumn{2}{|c|}{ Value } \\
\hline & Varas & $\%$ & Maravedis & $\%$ \\
\hline Bed linens & $3,253.6$ & 17.98 & $219,928.0$ & 20.28 \\
\hline Shirts & $3,081.4$ & 17.03 & $169,455.5$ & 15.62 \\
\hline Table linens & $7,732.5$ & 42.74 & $485,536.5$ & 44.76 \\
\hline Rest & $4,023.6$ & 22.24 & $209,741.0$ & 19.34 \\
\hline Total & $18,091.1$ & 100.00 & $1,084,661.0$ & 100.00 \\
\hline
\end{tabular}


Table 6

Garments with linings: distribution by type of lining

\begin{tabular}{lccccccc} 
& \multicolumn{2}{c}{ Fabric lining } & & & Fur lining \\
& Items & Cheaper & Similar & $\begin{array}{c}\text { More } \\
\text { expensive }\end{array}$ & Items & Cheaper & Similar \\
expensive
\end{tabular}

Notes: Cheaper: the lining is at least $10 \%$ cheaper than the fabric; More expensive: the lining is at least $10 \%$ more expensive than front. In case of garments made with fabrics, the ratios of prices per vara are computed. When the garments are made of fabrics and furs, the total cost of lining and front are compared.

volume via hooped underskirts, became visible in the last third of the 15 th century. Women were already used to the habit of covering their heads. The Spanish headdress consisted of braiding the hair into a bun at the back of the head and then wearing a cloth or braided cap. By the end of the 15th century, the preference for shorter, upswept hair standardized the coif or albanega, and sometimes on this was added a clear toque. There was also the use of bonetes (sort of caps) among women. All these changes comprise Spanish style, and it spread elsewhere.

New fashions were quickly made to emulate the wealthiest, but people of humble origin could hardly afford to follow new trends. Siguienza stated that the majority of the population wore ordinary, home-made clothing [52, pp. 359-60].

\section{Linings}

Bernis and Martínez note that the outfit of the time was both inner and outer garments plus attire for the head, feet and hands [48-50]. Some of these garments were lined and complemented with ornaments. Some outer dresses, such as the hopa, in fashion from the middle of the 14th century, were lined with fur [52, p. 356] or other rich fabric [36, p. 20].

Although most of the garments described in Accounts of the treasurer did not include lining, some dresses had it probably when the fabric was in direct contact with the skin or to protect some fabrics to last longer. The lining might be the same fur or fabric as used for the outer clothing, as highlighted by the source. Isabel purchased white velvet to line a mongil made of green velvet, white damask to line a brocade de cama (bed brocade), dyed linen to line stoles and manipulos made from green and purple cebty; and black satin to line lobas and habits.

We attempted to relate the prices of linings with the prices of outer fabric, that is, the part seen by others. In doing so, we classified linings into two categories: fur, and other fabric such as wool or silk. Table 6 shows that in
$56 \%$ of the cases, lining with fur was more expensive than the fabric used for the outside of the garment. The look of the fur seems secondary in these cases because it was not visible, and was often made from cats, ermines, rabbits or martens.

The same thing occurred with clothes lined with other fabrics: in $40 \%$ of the cases we found, the price of the lining fabrics was more expensive or similar to the fabric for the outside of the garment. In the case of the royal family, this rises to $46 \%$. In many cases, the lining offered a contrast in colour, and it is very likely that the lining's texture, would be as important as its colour and price. It is true that the only lined garments known to have been worn directly on the skin were hose, but there are no reasons to suggest linings would also be in contact with some parts of the body taking into account the type of fabrics and furs of the inner fabrics.

Table 7 shows the total type of materials used for linings versus outer garments. Looking at the outer fabric of the 57 lined items (rows 1-3), 46 were silk, nine wool, one linen and one other (fustian). In $52.6 \%$ of the cases, silk was used for both linings and outer garments (as was the case for bonete, capuz, gabán, gonete, hábito, mantil-

Table 7

Garments with linings: distribution by type of lining and outer fabric

\begin{tabular}{|c|c|c|c|c|c|}
\hline \multirow{2}{*}{ Lining } & \multicolumn{5}{|c|}{ Outer fabric } \\
\hline & Silk & Wool & Linen & Other & Total \\
\hline Silk & 30 & 3 & - & - & 33 \\
\hline Wool & 14 & 4 & - & - & 18 \\
\hline Linen & 2 & 2 & 1 & 1 & 6 \\
\hline Fur & 23 & 3 & - & 1 & 27 \\
\hline Total & 69 & 12 & 1 & 2 & 84 \\
\hline
\end{tabular}


la, marlota, paletoque, papahígo, sayo). In almost $30 \%$ of the cases, silk was combined with wool (silk for outer garments in $24.6 \%$ of the items (ropón, mongil, gonete and faldrilla) and for lining in $5.3 \%$ (habit and gonete). Both components were made in wool in $7 \%$ of the items (calzas), and the remaining $10 \%$ were six garments lined with linen (skirt, smock, cotte, faldrilla, jubón) with the exterior made from silk (2), linen (1), fustian (1) and wool (2).

Looking at the total of 27 garments lined with fur (row 4), $85 \%$ of the outer fabrics were silk, and the lining was ermine or rabbit in $59 \%$ of the cases. The fur for one item was to line a pair of gloves. For the other items, the fur was used as follows:

- ermine combined with silk (8 garments: ropa larga, mongil, gonete, mantillas, sayo);

- rabbit combined with silk (5) and wool (2) (7 garments: hábitos, mongiles, ropón);

- black pena combined with silk (3 garments: ropones, mongil);

- black navarrisca pena combined with silk (2 ropones);

- black frisol pena combined with silk (2 mantillas);

- marta cibelina (sable lining) combined with silk (2 garments: gonete and sayo);

- pena negra de romanea combined with wool (1 ropón);

- squirrel combined with wool (1 hábito de seda );

- pelleja de Romania.

\section{Social stratum: the Queen, prince, nobility and the poor}

We now dig a little deeper by social stratum. Although it is possible to measure the amount of fabrics in relation to other social groups (servers, guards, dames) and certain royal officials, we focus our analysis on those groups that offer the most reliable data: the Queen; the nobility (represented by the elder son of the Duke of Braganza, who was of similar age to the heir apparent); and the poor as dressed by the Queen on certain occasions.

Between 1492 and 1504, the Queen accounted for nearly $22 \%$ of the total spent, which was slightly more than her $20 \%$ total between 1483 and 1491. Silk represented three-quarters of that expenditure, and the remainder was linen, followed by wool. In quantity, $70 \%$ of the fabrics used for the Queen was linen, followed, in order, by silk and wool (Table 8).

The data highlights what is already well known: silk was the fabric of the royalty to show wealth. In their domestic life, however, linen played a prominent role too, as bedding, tablecloths, towels, sheets, pillows, and mattresses.

For the comparison to Isabel, we have the data between 1492 to 1495 of the fabrics related to Prince Don Juan, the heir to the Crown, and Don Jaime de Braganza, the firstborn of a Portuguese nobleman who sought refuge in the court. Both boys were about the same age. Prince Don Juan used, on average, almost seven times as much fabric as Don Jaime, which cost nearly eight and a half times more than the amount spent on Don Jaime. The prince used an extensive array of expensive fabrics. In relative terms, he consumed less wool in both quantity and value but more linen, at least in quantity. Both Don Juan and Don Jaime used similar percentages of silk in quantity, but not value. High nobility often dressed in silk, but it was less expensive than the silk used for royalty [30, 53].

Of the silk fabrics purchased by the Royal House, the most expensive was brocade, followed by altibajo, villutado and carmesi de pelo. The most commonly used fabric was generic velvet, which represented half of the total number of varas and almost a similar percentage in value. Not surprisingly, two-thirds of the total expenditure was spent on the costly velvets and brocades. Satins, damasks and cebtyes together represented $38 \%$ of silk purchases.

At the other end of the socio-economic ladder were the pobres (poor), which was the term used in Accounts of the treasurer. In actuality, they were pobres de solemnidad (beggars). We have taken into account fabrics for clothing donated by the Queen to nine poor women and 13 poor men that she dressed for special occasions, in particular for two annual festivities: Our Lady of March and the Last Supper (Maundy Thursday).

Each man was given between 6.5 and 7 varas (approx. 5.8 meters) of cheap paño pardillo and buriel, costing

\section{Table 8}

Consumption attributed to the Queen (1492-1504), and the Prince and Don Jaime (1492-1495)

\begin{tabular}{|c|c|c|c|c|c|c|}
\hline \multirow{2}{*}{ Fiber } & \multicolumn{2}{|c|}{ Queen } & \multicolumn{2}{|c|}{ Prince } & \multicolumn{2}{|c|}{ Don Jaime } \\
\hline & Varas $(\%)$ & Maravedis (\%) & Varas $(\%)$ & Maravedis (\%) & Varas (\%) & Maravedis (\%) \\
\hline Linen & 70.20 & 14.93 & 59.56 & 6.71 & 47.13 & 7.15 \\
\hline Silk & 22.27 & 75.21 & 28.32 & 81.16 & 27.60 & 66.27 \\
\hline Wool & 7.27 & 9.77 & 10.83 & 12.07 & 25.27 & 26.58 \\
\hline Other & 0.26 & 0.09 & 1.29 & 0.06 & - & - \\
\hline Total & 100.00 & 100.00 & 100.00 & 100.00 & 100.00 & 100.00 \\
\hline
\end{tabular}


Table 9

Woollen fabrics, colour and price in percentage of varas and maravedis (1492-1504)

\begin{tabular}{|c|c|c|c|c|c|c|}
\hline & \multicolumn{3}{|c|}{ Quantity of fabrics per price group (\%) } & \multicolumn{3}{|c|}{ Value of fabrics per price group (\%) } \\
\hline & $\begin{array}{c}100-399 \\
\mathrm{mrs} / \text { vara }\end{array}$ & $\begin{array}{l}400-999 \\
\text { mrs / vara }\end{array}$ & $\begin{array}{l}>1000 \\
\mathrm{mrs} / \text { vara }\end{array}$ & $\begin{array}{l}\text { 100-399 } \\
\text { mrs / vara }\end{array}$ & $\begin{array}{l}\text { 400-999 } \\
\text { mrs / vara }\end{array}$ & $\begin{array}{c}>1000 \\
\text { mrs / vara }\end{array}$ \\
\hline Black (negro) & 21.45 & 9.54 & 10.10 & 24.52 & 8.98 & 10.02 \\
\hline Brown (pardillo) & 20.25 & 0.52 & 0.00 & 15.06 & 0.47 & 0.00 \\
\hline Green (verde) & 4.18 & 3.54 & 0.00 & 7.85 & 3.49 & 0.00 \\
\hline Blended (combinado) & 3.26 & 3.80 & 1.79 & 2.80 & 3.41 & 1.68 \\
\hline Violet (morado) & 1.55 & 8.17 & 7.10 & 2.90 & 8.57 & 7.02 \\
\hline White (blanco) & 1.51 & 0.95 & 0.00 & 1.1 & 0.76 & 0.00 \\
\hline Blue (azul) & 1.24 & 0.64 & 0.00 & 1.39 & 0.83 & 0.00 \\
\hline Red (colorado) & 0.91 & 2.67 & 34.59 & 1.31 & 3.90 & 35.42 \\
\hline Pink (rosado) & 0.28 & 1.07 & 3.14 & 0.44 & 0.79 & 3.21 \\
\hline Tawny (leonado) & 0.24 & 0.33 & 0.00 & 0.16 & 0.34 & 0.00 \\
\hline Scarlett (grana)* & 0.10 & 3.20 & 40.58 & 0.15 & 4.85 & 40.22 \\
\hline Golden (dorado) & 0.10 & 0.60 & 0.00 & 0.09 & 0.55 & 0.00 \\
\hline Yellow (amarillo) & 0.05 & 0.24 & 0.00 & 0.10 & 0.25 & 0.00 \\
\hline Snow-white (nevado) & 0.00 & 1.97 & 0.00 & 0.00 & 1.93 & 0.00 \\
\hline Silver (plateado) & 0.00 & 0.17 & 0.00 & 0.00 & 0.16 & 0.00 \\
\hline Deep blue (turqués) & 0.00 & 0.03 & 0.00 & 0.00 & 0.03 & 0.00 \\
\hline Unknown & 44.88 & 62.58 & 2.70 & 40.07 & 60.68 & 2.43 \\
\hline Total & 100.00 & 100.00 & 100.00 & 100.00 & 100.00 & 100.00 \\
\hline
\end{tabular}

Note: It was noted an Orange Ruan but the price was not included.

* Expenditure in grana.

73-175 mrs/vara, and four additional varas (approx. 3.3 meters ) of Bretagne linen costing $31 \mathrm{mrs} / \mathrm{vara}$. Each woman received 9 varas ( 7.5 meters) of these same cheap woollen cloths at 73-78 mrs/vara and between 4.5 and 5.5 varas (approx. 4 meters) of Bretagne linen, also at $31 \mathrm{mrs} /$ vara. The linen was to be used for shirts, and the wool for sayos and capuces. A donation was also made to one poor girl for a saya (cotte), caps and shoes for a total value of 500 mrs [36, p. 588].

\section{Colours}

According to Sigüenza, clothes differed according to social strata, gender, age, profession and religion (by iconography; e.g. Retablo de San Juan Bautista by Pedro García de Benabarre) [52, p. 360]. There is no doubt that clothing played important roles as instruments of power and prestige, and even as elements of propaganda. While it is now difficult to understand the symbolism in the donation of fabrics from kings to nobility or the effectiveness of sumptuary laws, it is clear that fabric marked stratifications - income, social position, and even religion [50, pp. 348-349]. This was also conveyed by the colour of the fabric. The accounts of the House of the Queen leave no doubt in this regard. The colours recorded in the accounts are not the same as we would identify today due to the quality of fabric, the dyes and the dyeing method used [32; 22, p. 69]. The purpose of this article is not to elaborate disquisitions, but to detail the fabrics used and to show how colour too marked social rank [54]. The significance of colours over history has changed, for example the use of blue in the 13th century and of black in the 15th century) [55]. According to Abel [26, p. 447], even if there were few new dyes, the transfer of knowledge improved with changes in transportation. Dyes are mostly water soluble, which allow colours to impregnate the fibres. Before 19th century, dyes were extracted from nature (vegetable or animal; e.g. leaves and lichens or insects and mollusks, respectively). This changed with the arrival of chemical substitutes and invention of coal tar dyes [31, p. 414]. 
The Accounts of the treasurer also provides colours for silk and wool, but rarely for linens, as those were mostly used bleached or in its natural hue. For wool, we established a classification: from 100-399, 400-999, and above $999 \mathrm{mrs} / \mathrm{vara}$. Data for the middle category is limited because we found information for only $37 \%$ of the varas in that group (Table 9).

Common folk dressed in black, sparrow and brownishgrey, which are the natural colours of wool. Nearly $50 \%$ of low-quality fabrics were not dyed.

For expensive fabrics, red shades were predominant (75\% of varas). González Arce pointed out that only the king was allowed to wear scarlet [56, p. 124]. Red was used as a liturgical colour to refer to the blood of Christ and to the Holy Spirit as a flame [25, p. 245]. Reds were used in the Middle Ages for royalty and nobility, who appreciated the colour not only for its symbolism but also because the dyes were expensive. The late medieval recipes of dyers, such as those collected by Joanet Valero in 1497, show the importance of red in all its ranges, including purple: three-quarters of the recipes are for red, while black and green account for only $10 \%$ each of the other recipes [25, p. 255 note 40$]$.
What is noticeable is the minimal to zero use of blue, yellow, tawny, snow-white, silver, turquoise. As an anecdote, yellow and green were associated in Accounts of the treasurer with "Crazy woman" [36, p. 401], although they were not always connected to madness. Yellow does not appear in expensive cloths, and it had a negative and pejorative meaning linked not only with Jews and Muslims but also with disease, avarice and betrayal [ 57 , 25].

In the most expensive silks, we found predominately black (in $45 \%$ of the cases), crimson or red (18\%) and green $(11 \%)$. One of these was used in at least $75 \%$ of the varas (Table 10). Since silk was only worn by royalty and nobility, black fit well with the message they wanted to convey, as many European nobles wore it, probably from the influence of the Italian bourgeoisie [23, pp. 188189]. Black was also the colour used by the clergy. It was a difficult and expensive colour to obtain. Only Benedictine monks managed to create an intense and luminous black dye at the end of the 14th century and the beginning of the 15th century [58-59]. The main problem with black dyes was that they tended to erode fibres and to fade. The discovery of America would bring a new natural black

Table 10

Silk fabrics sorted by colour, in varas (\%) (1492-1504)

\begin{tabular}{|c|c|c|c|c|c|c|c|c|c|c|c|}
\hline & 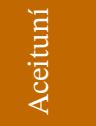 & 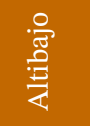 & 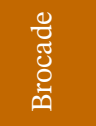 & 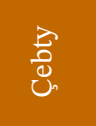 & 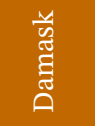 & $\stackrel{\Xi}{\overparen{\Xi}}$ & 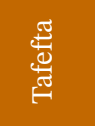 & $\frac{\overrightarrow{\mathrm{N}}}{\stackrel{\rho}{\rho}}$ & $\begin{array}{l}\text { 을 } \\
\text { 莺 } \\
\text { 号 }\end{array}$ & $\begin{array}{l}\vec{y} \\
\text { 幽 }\end{array}$ & 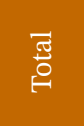 \\
\hline Black (negro) & 33.9 & 0.0 & 14.2 & 35.4 & 27.3 & 36.4 & 11.7 & 62.1 & 15.7 & 1.6 & 45.0 \\
\hline Crimson (carmesí) & 37.5 & 53.2 & 50.5 & 27.0 & 2.9 & 23.2 & 0.0 & 14.4 & 11.8 & 29.7 & 18.5 \\
\hline Green (verde) & 7.4 & 15.9 & 0.3 & 4.9 & 15.6 & 19.6 & 1.5 & 10.6 & 14.4 & 0.7 & 11.3 \\
\hline Violet (morado) & 16.7 & 0.8 & 16.5 & 5.9 & 3.0 & 10.8 & 0.0 & 4.5 & 23.6 & 9.4 & 6.4 \\
\hline White (blanco) & 0.0 & 0.0 & 16.6 & 10.2 & 26.4 & 4.3 & 0.0 & 0.2 & 0.0 & 0.0 & 5.7 \\
\hline Blended (combinado) & 0.0 & 0.0 & 0.0 & 0.5 & 5.5 & 0.0 & 56.1 & 0.6 & 34.4 & 11.7 & 2.3 \\
\hline Blue (azul) & 4.6 & 13.9 & 0.0 & 2.2 & 3.4 & 0.6 & 0.0 & 1.1 & 0.0 & 0.0 & 1.6 \\
\hline Brown (pardillo) & 0.0 & 0.0 & 0.3 & 4.9 & 3.5 & 1.3 & 0.0 & 0.0 & 0.0 & 0.0 & 1.1 \\
\hline Deep Blue (turqués) & 0.0 & 0.0 & 0.0 & 1.8 & 2.5 & 0.4 & 7.50 & 0.0 & 0.0 & 0.0 & 0.7 \\
\hline Scarlett (grana) & 0.0 & 0.0 & 0.0 & 3.1 & 0.0 & 0.0 & 20.0 & 0.0 & 0.0 & 0.0 & 0.6 \\
\hline Yellow (amarillo) & 0.0 & 16.2 & 0.0 & 1.6 & 0.0 & 0.9 & 0.0 & 0.0 & 0.0 & 0.0 & 0.6 \\
\hline Tawny (leonado) & 0.0 & 0.0 & 0.8 & 0.1 & 0.0 & 0.8 & 0.0 & 0.6 & 0.0 & 0.0 & 0.5 \\
\hline Orange (naranjado) & 0.0 & 0.0 & 0.0 & 1.1 & 1.0 & 0.7 & 0.0 & 0.0 & 0.0 & 0.0 & 0.3 \\
\hline Red (colorado) & 0.0 & 0.0 & 0.0 & 0.0 & 2.4 & 0.0 & 3.0 & 0.0 & 0.0 & 0.0 & 0.3 \\
\hline Blood-red (encarnado) & 0.0 & 0.0 & 0.0 & 0.0 & 0.0 & 0.9 & 0.0 & 0.0 & 0.0 & 0.0 & 0.1 \\
\hline Unknown & 0.0 & 0.0 & 0.7 & 1.3 & 6.5 & 0.1 & 0.2 & 5.9 & 0.0 & 46.8 & 4.9 \\
\hline Total & 100.0 & 100.0 & 100.0 & 100.0 & 100.0 & 100.0 & 100.0 & 100.0 & 100.0 & 100.0 & 100.0 \\
\hline
\end{tabular}


dye, the Palo de Campeche, which was a less expensive dye and of great quality [39, p.7].

Reds were easier to achieve than black. The female kermes was used to make the "first luxury dye of the Middle Ages" [26, p. 440]. Before the arrival of the cochinille from America, kermes vermilio and kerria lacca were the most common insects used for making red dye [60, p. 127]. At the time, travelers seemed to identify terciopelo carmesi (crimson velvet) with Spain. Thus, the Moorish influence was also present [61, p. 13].

With the discovery of America and South American woods, Europe found abundant sources for new ways of dyind red. Since 13th century an expensive red dye made from the Guilandina Equinea came from the East Indies and Sri Lanka. However, a tree of the same species (brazilwood) was discover in South America and became one of the most lucrative trades from the Portuguese colony to the European markets. On the other hand, cochineal insects, which lived on cacti in New Spain, provided also a red dye, during the period of the Catholic Kings, as did the coccus ilicis, also known as kermes, which lived on Mediterranean evergreen oaks.

More complex than red was the green, which together with the black is present in all kinds of tissues. In fact, black, red and green were used on all types of fabrics. In the case of the taffeta, all colours except crimson and purple were used (Table 10). For yellow, the dyes most likely came from reseda, an herbaceous plant with yellow flowers, along with fustete (young fustic), safflower and saffron [26, p. 441].

Data collected from 1492 gives the impression that colour was also used for some linens, a fabric most often used unbleached and without colour. It is likely that very white linens were the most expensive. In the case of the most used linen fabrics (Brittany, naval and linen without specific description), $7 \%$ were dyed, some in blue. Twelve percent of naval linen and $30 \%$ of the other linen had no description of colour. The listed colours include black and blue, followed by green, yellow and tawny. Sánchez Ortiz [62] and Piponnier [23] pointed out that blue emerged strongly in medieval Europe to compete with red; between 1180 and 1250, dyers achieved an intense and brilliant blue. In the 11th and 13th centuries, Europe used blue as it was associated with the light of God and with the Virgin Mary, who appears in iconography wearing a mantle or dress of that colour [63, p. 22]. Improvements were made in the 14th century by mixing lapis lazuli with mineral wax, oil and resin to create the colour ultramarine, also used in paintings associated with sacred objects of the Virgin Mary. "Lapis Lazuli was known as the Queen of pigments because it comes from a semi-precious stone that was pulverise and use as a pigment from Egypt to China" [29, p. 449].

White is also noted, which probably means that the items had been treated in a special way to lighten them, as most white fabrics were not dyed at all. The mention of dying linen could mean either a new fashion or just further details of the accounting officer.

\section{Conclusion}

The purpose of our research was to use the information provided by Gonzalo de Baeza to create a systematic database on the evolution of fabric usage in the Royal House of Isabel I by type, value, quantity, social class and colours.

In line with Zalama [38], we can ascertain that the House of Isabel I was not austere. While the most used fabric was the less expensive linen, it was used for bedding, tablecloths and napkins, and wrappings to move household items, or for only partially visible garments (such as shirts). Linen's significance during the period in general, however, has gone largely unnoticed because post-mortem inventories tended not to include it, as such garments were mostly donated to the poor or destroyed for sanitation reasons. However, it is also important to note that archaeological finds and iconography shows the use of shirts and smocks by all classes. Notwithstanding, it is necessary further research.

The advantages of linen are many, the most obvious being its durability and resistance to wear and tear [64]. Another great advantage is that it stays light and cool in summer and absorbs perspiration, making it ideal for bedding. Flax is one of the few fibres that can eliminate and neutralize odours, washable and widely produced and available throughout Europe, which is why it was used in the home and as undergarments [65]. Linen was thus also an ideal fibre for furnishing textiles (holanda and lienzo encerado or oil-linen for windows [36, pp. 42, 261]) and utilitarian objects (e.g. tablecloths).

In the Accounts of the treasurer, nobility and royalty used linen, especially expensive Holland linen, for shirts. Gonzalo de Baeza offers no information about linen's importance among other social groups, although we can assume that it was important in the bedroom and common in undergarments, mostly, but rarely used in outer layers. Home linen was very common, even if it was rarely marketed or commercialised like wool and silk fabrics. Silk was reserved for royalty and nobility while wool was used by those of lesser means. Scott noted that "wool was made into every kind of outer garment, from stockings to hoods to gowns", and was associated with lower income [47, p. 17]. Linen seems to have been present at all social levels due to its versatility [65, p. 138].

According to Bernis, only calzas and bragas were considered undergarments and were limited in their use [48]; thus most outer garments were probably in direct contact with the skin. Guindon poins out, quoting Vigarello, "le linge de dessous existait déjà au Moyen Âge, mais que son statut était si peu important qu'on n'en possédait qu'un. Son seul intérêt consistait à être confortable pour la peau" [66-67]. Seen only in the upper classes were garments with linings, and only those garments of great value. Lining could be fur - from ermine to cats - which was appreciated not only for its rich appearance but also for its warmth (until the 12th century, fur was used for its warmth, not for fashion or status). The 
colour of the fur became an important marker, as did the fur's softness (e.g. for blankets).

The use of expensive linens and expensive fabrics and furs as linings suggests that, apart from highlighting their social standing through clothing, royalty and nobility likely considered fur and other lining fabrics for both comfort and protection against the cold. However, adornment and protection from the cold were not the same thing [68]; the quality of the furs used and their particular use in garments made clothing both a fashion and status statement.

Fur and silk competed as the luxury materials for the upper class, but silk would eventually become more popular. This explains the increase in the use of silks as incomes increased: "la fourrure gardera ses vertus contre le froid, mais la soie lui fera au XVème siècle une sérieuse concurrence sur le marché du luxe" [68].

The colour of garments was also a significant element: it conveyed social standing, up or down, through the use or absence of expensive dyes. It is possible that colour had a further symbolic role, but our statistical data reveals that, while other colours were used, variations of red and black dominated.

The type of dyed fibre also held relevance. Black, crimson-red and green, respectively, were the dominant colours for silks. For expensive woollen cloths, the dominant colour was grana (red dye), and black seems to have been the dominant colour for cheap woollen fabrics. From Accounts of the treasurer, a relevant percentage of cheap and medium-priced fabric did not include mention of colour, thus no other firm conclusions can be drawn. The predominant colours used for expensive woollen fabric were not different from those used for silk, although their order changed: scarlet, red and black were most often used for expensive woollen fabric, while black and red were used for silks. Thus, shades of red and black were always dominant, but they swapped places according to fabric being dyed.

\section{Acknowledgements}

We acknowledge research funding from Ministerio de Economía, Industria y Competitividad (Agencia Estatal de Investigación)/Fondo Europeo de Desarrollo Regional (FEDER), HAR 2016-78026-P. We are grateful to Ana Cabrera and Eva Fernández de Pinedo, who kindly provided technical support. We are also very thankful to the reviewers for their comments and suggestions.

\section{ORCID}

Nadia Fernández de Pinedo

(iD) https://orcid.org/0000-0001-6708-1480

\section{References}

1 Aymard, M.; Romani, M. A. (eds.), La Cour comme institution économique, París, (1998).
2 Adamson, J. (ed.), The Princely Courts of Europe. Ritual, Politics and Culture Under the «Anden Régime»1500-1750, London, (1999).

3 Bernáldez, A., Historia de los Reyes Católicos Don Fernando y Doña Isabel, Luciano de la Calzada, Madrid (1946).

4 De La Torre, A., La Casa de Isabel la Católica, CSIC Patronato Marcelino Menéndez Pelayo, Madrid (1954).

5 Ladero Quesada, M. A. (ed.), La Sociedad Castellana a Finales del Siglo XV, DYKINSON, Madrid (2004).

6 Ladero Quesada, M. A., 'La hacienda real de Castilla en 1504. Rentas y gastos de la Corona al morir Isabel I', Historia, Instituciones, Documentos, 3 (1976), 326-330.

7 Ladero Quesada, M. A., La Armada de Flandes: un Episodio en la Política Naval de los Reyes Católicos (1496-1497), Real Academia de la Historia, Madrid, (2003).

8 Leroy, B., L'Historien et son Roi. Essai sur les Chroniques Castillanes, XIV-XV siécles, Madrid, (2013).

9 Martínez Ruiz, E., Tradición y Novedad en la Organización Político-administrativa de la Corona de Castilla en el Reinado de los Reyes Católicos, Chronica Nova, Madrid (1993).

10 Pérez, J., Isabel y Fernando. Los Reyes Católicos, Madrid (1988).

11 Valdeón Baruque, J., Sociedad y Economía en Tiempos de Isabel la Católica, Valladolid (2002).

12 Hernández Martínez, P., 'La memoria de la historia oficial: Crónicas y cronistas en la España de los Reyes Católicos', Revista EPCCM 15 (2013) 235-268.

13 Braudel, F., Civilisation Matérielle, Économie et Capitalisme, XVe-XVIIIe siècle. 1. Les Structures du Quotidien: le Possible et l'Impossible, Armand Colin, Paris (1979).

14 Rumeu de Armas, A., Itinerario de los Reyes Católicos (14741516), CSIC, Madrid, (1974).

15 Fernández de Córdova Miralles, A., 'Sociedad cortesana y entorno regio', Medievalismo: Boletín de la Sociedad Española de Estudios Medievales 13-14 (2004) 49-78.

16 Pelaz Florez, D., 'La imagen de la reina consorte como muestra de poder en el reino de Castilla durante el siglo XV. Construcción y significado', Medievalismo: Boletín de la Sociedad Española de Estudios Medievales 23 (2013) 265-90.

17 Levas Cuevas, J., 'El vestido y las leyes suntuarias como configuradores de la industria textil. La collación de Santa María en la Córdoba Bajomedieval', Ámbitos: Revista de Estudios de Ciencias Sociales y Humanidades 3 (2009) 11-20.

18 Bernis, C., Trajes y Modas en la España de los Reyes Católicos I. Las Mujeres, 2 vols., C.S.I.C., Madrid (1978).

19 Sempere y Guarinos, J., Historia del Luxo y de las Leyes Suntuarias de España, vol. 1, Madrid (1788).

20 Gérard-Marchant, L., 'Compter et nommer l'étoffe à Florence au Trecento (1343)', Médiévales: Langue, Textes, Histoire 14(29) (1995) 87-104, https://doi.org/10.3406/ medi.1995.1339.

21 Rodríguez-Velasco, J. D., Ciudadanía, Soberanía Monárquica y Caballería: Poética del Orden de Caballería, Akal, Madrid (2009), p.128.

22 Buss, C., 'Tessuti e colori svelati. La «magna curia» mantovana del 1340. Glossario', in I Gonzaga: Cavalieri, Vesti, Argenti, Vino: La «Magna Curia» del 1340, ed. C. Buss \& D. Ferrari, Silvana, Milano (2016).

23 Piponnier, F., Costume et Vie Sociale. La Cour d'Anjou. XIVeXVe Siècles, Mouton, Paris-La Haye (1970), pp.188-196.

24 Hayward, M., Rich Apparel, Clothing and the Law in Henry's VII England, Ashgate, Burlington (2009), pp.17-21.

25 de Sas van Damme, A., 'El amarillo en la Baja Edad Media. Color de traidores, herejes y repudiados', Estudios Medievales Hispánicos 2 (2013) 241-76. 
26 Abel, A., 'The history of dyes and pigments: From natural dyes to high performance pigments', in Colour Design: Theories and Applications, ed. J. Best, Woodhead Publishing, Cambridge (2012) 433-470.

27 Ferreira, M. J., 'Asian textiles in the Carreira da Índia: Portuguese trade, consumption and taste', Textil History 46(1) (2015) 147-168, https://doi.org/10.1080/00404969.2015.1121 663.

28 Cardon, D., Natural Dyes: Sources, Tradition, Technology and Science, Archetype, London (2007).

29 Iradiel Muruagarren, P., La Evolución de la Industria Textil Castellana en los Siglos XIII-XVI: Factores de Desarrollo, Organización y Costes de la Producción Manufacturera en Cuenca, Universidad de Salamanca, Salamanca (1974), pp.122-130.

30 Piponnier, F.; Mane, P., Se Vêtir au Moyen Âge, Biro, Paris (1995), p.73, 131.

31 Schneider, J. 'Peacocks and penguins: the political economy of European cloth and colors', American Ethnologist 5(3) (1978) 413-447, https://doi.org/10.1525/ae.1978.5.3.02a00010.

32 Finlay, R., 'Weaving the rainbow: visions of color in world history', Journal of World History 18(4) (2007) 383-431, https://doi.org/10.1353/jwh.2008.0001.

33 González Marrero, M.C., La Casa de Isabel la Católica. Espacios Domésticos y Vida Cotidiana, Institución Gran Duque de Alba, Ávila (2006).

34 Saénz de Miera, J., 'Instrumentos suntuarias para una nueva dignidad real: útiles y objetos precisos pertenecientes a Isabel I de Castilla', in Isabel la Católica la Magnificencia de un Reinado: Quinto Centenario de Isabel la Católica, 1504-2004, Sociedad Estatal de Conmemoraciones Culturales, (2004) 155-168.

35 de la Torre y del Cerro, A., Testamentaria de Isabel la Católica, Instituto Isabel la Católica de Historia Eclesiástica, Valladolid (1968).

36 de la Torre, A.; de la Torre, E. A. (ed.), Cuentas de Gonzalo de Baeza, Tesorero de Isabel la Católica, vol. 1 (1477-1491) and vol. 2 (1492-1506), CSIC, Patronato Menéndez Pelayo, Madrid (1955).

37 Fernández de Pinedo Fernández, E.; Moral Zuazo, M. P., 'Vísteme despacio... El consumo de tejidos por la Casa Real de Isabel I a fines del siglo XV', in Modernidad de España. Apertura Europea e Integración Atlántica, ed. A. M. Bernal, Marcial Pons, Madrid (2017) 569-596.

38 Zalama Rodríguez, M.A. 'Oro, perlas, brocados...: la ostentación en el vestir en la corte de los Reyes Católicos', Revista de Estudios Colombinos 8 (2012) 13-22.

39 Cabrera, A., 'Los tejidos como patrimonio: investigación y exposición', Revista del Instituto del Patrimonio Histórico Español 5 (2005) 5-19.

40 Diccionario de Autoridades, Real Academia Española, 3 vols., facsimile, Gredos, Madrid (1963).

41 Corominas, J.; Pascual, J. A., Diccionario Crítico Etimológico Castellano e Hispánico, 6 vols., Gredos, Madrid, (1980-1991).

42 Covarrubias, S., Tesoro de la Lengua Castellana o Española, facsimile, Alta Fulla, Barcelona (1998).

43 Castany Saladrigas, F., Diccionario de Tejidos: Etimología, Origen, Arte, Historia y Fabricación de los Más Importantes Tejidos Clásicos y Modernos, Gustavo Gili, Barcelona (1949).

44 Gual Camarena, M., Vocabulario del Comercio Medieval, Universidad de Murcia (2014), http://www.um.es/lexicocomercio-medieval (accessed 2018-5-18).

45 Nemnich, P. A., An Universal European Dictionary of Merchandise, in the English, German, Dutch, Danish, Swedish, French, Italian, Spanish, Portuguese, Russian, Polish \& Latin Languages, J. Johnson, London (1799).
46 Beck, S.W., The Draper's Dictionary: a Manual of Textile Fabrics: their History and Applications, The Warehousemen \& draper's journal office, London (1882), https://archive.org/ details/drapersdictionar00beck (accesed 2018-5-18).

47 Scott, M., Fashion in the Middle Ages, Getty Publications, L.A. California, (2011).

48 Bernis, C., Indumentaria Medieval Española, Instituto Diego Velázquez, CSIC, Madrid (1953), pp. 35-53.

49 García Marsilla, J. V., 'La moda no es capricho. Mensajes y funciones del vestido en la Edad Media', Vínculos de Historia. Revista del Departamento de Historia de la Universidad de Castilla-La Mancha 6 (2017) 71-88, https://doi.org/10.18239/ vdh.v0i6.269.

50 Martínez, M., 'La creación de una moda propia en la España de los Reyes Católicos', Aragón en la Edad Media 19 (2006) 343-380.

51 Descalzo, A., 'Vestirse a la moda en la España moderno', Vinculos de Historia 6 (2017) 105-134, https://doi. org/10.18239/vdh.v0i6.271.

52 Sigüenza Pelarda, C., 'La vida cotidiana en la Edad Media: la moda en el vestir en la pintura gótica', in La Vida Cotidiana en la Edad Media: Actas de la VIII Semana de Estudios Medievales: Nájera, del 4 al 8 de agosto de 1997, Instituto de Estudios Riojanos (1998) 353-368.

53 Sivéry, G., La Baja Edad Media: ¿Espejismos Mediterráneos o Realidades Atlánticas? (Siglos XIII-XV), Edaf, Madrid (1976).

54 Gheerbrant, A.; Chevalier, J., Dictionnaire des Symboles. Mythes, Rêves, Coutumes, Gestes, Formes, Figures, Couleurs, Nombres, 2nd ed., Robert Laffont S.A. - Ed. Jupiter, Paris (1982), pp. 671-674.

55 Pastoureau, M., Jésus chez le Teinturier. Couleurs et Teintures dans l'Occident Médiéval, Le Léopard d'Or, Paris (1997).

56 González Arce, J.D., Apariencia y Poder: la Legislación Suntuaria Castellana en los Siglos XIII y XV, Universidad de Jaén, Jaén (1998).

57 Hickey, H. 'Medical diagnosis and the colour yellow in early Modern England, E-rea, 12(2) (2015), https://doi. org/10.4000/erea.4413.

58 Pastoureau, M., 'Du bleu au noir. Éthiques et pratiques de la couleur à la fin du Moyen Âge', Médiévales: Langue, Textes, Histoire 14 (1988) 9-21, https://doi.org/10.3406/ medi.1988.1097.

59 Pastoureau, M., 'Jésus teinturier. Histoire symbolique et sociale d'un métier réprouvé', Médiévales: Langue, Textes, Histoire 29 (1995) 47-63, https://doi.org/10.3406/ medi.1995.1336.

60 Gayo, M. D.; Arteaga, A. 'Análisis de colorantes de un grupo de tejidos hispanomusulmanes', Bienes Culturales 5 (2005) 123-145.

61 Silva Santa-Cruz, N., 'La Corte de los Reyes Católicos y el reino nazarí. Permeabilidad cultural e intercambios artístico', in El Arte en la Corte de los Reyes Católicos. Rutas Artísticas a Principios de la Edad Moderna, ed. C. Checa Cremades \& B. García García, Fundación Carlos de Amberes, Madrid, (2005) 272-282.

62 Sánchez Ortiz, A., 'El color: símbolo de poder y orden social. Apuntes para la historia de las apariencias en Europa, Espacio, Tiempo y Forma. Serie IV, Historia Moderna 12 (1999) 321-354.

63 Pastoureau, M.; Simonnet, D., Breve Historia de los Colores, Ediciones Paidós, Barcelona (2006).

64 Paddock Hess, K., Textile Fibers and Their Use, J.B. Lippincott Co., New York (1954).

65 Fennell Mazzaoui, M., The Italian Cotton Industry in the Later Middle Ages, 1100-1600, Cambridge University Press, Cambridge (1981). 
66 Guindon, A., L’Habillé et le Nu: Pour une Éthique du Vêtir et du Dénuder: Essai, University of Ottawa Press, Ottawa (1997).

67 Vigarello, G., Le Propre et le Sale. l'Hygiène du Corps Depuis le Moyen Âge, Seuil, Paris (1985).

68 Favier, J., Le Bourgeois de Paris au Moyen Âge, Tallandier, Paris (2015).

Received: 2018-6-16

Revised: 2018-11-30

Accepted: 2018-12-3

Online: 2019-1-29

(@) $\Theta \Theta$

This work is licensed under the Creative Commons Attribution-NonCommercial-NoDerivatives 4.0 International License. To view a copy of this license, visit http://creativecommons.org/licenses/by-nc-nd/4.0/deed.en. 